\title{
Author Correction: Improved genome recovery and integrated cell-size analyses of individual uncultured microbial cells and viral particles
}

\author{
Ramunas Stepanauskas (1) 1, Elizabeth A. Fergusson', Joseph Brown', Nicole J. Poulton', Ben Tupper ${ }^{1}$, \\ Jessica M. Labonté ${ }^{1,3}$, Eric D. Becraft ${ }^{1}$, Julia M. Brown ${ }^{1}$, Maria G. Pachiadaki ${ }^{1}$, Tadas Povilaitis ${ }^{2}$, \\ Brian P. Thompson ${ }^{1}$, Corianna J. Mascena', Wendy K. Bellows ${ }^{1} \&$ Arvydas Lubys $^{2}$
}

Nature Communications 8:84 doi:10.1038/s41467-017-00128-z; Article published online: 20 July 2017

The original version of this Article contained errors in the units of concentration of three reagents listed in the Methods section. In the first sentence of the 'Cell lysis' section of the Methods section, the concentration of KOH was incorrectly listed as 0.4 mM and should have read $0.4 \mathrm{M}$. In the penultimate sentence of the first paragraph of the 'Optimization and benchmarking of single-cell WGA-X' section of the Methods, the concentration of dNTP was incorrectly given as $0.4 \mu \mathrm{M}$ and should have read $0.4 \mathrm{mM}$. Finally, in the same sentence, the concentration of dithiothreitol was incorrectly given as $10 \mu \mathrm{M}$ and should have read $10 \mathrm{mM}$. These errors have all been corrected in both the PDF and HTML versions of the Article.

Published online: 12 December 2017

Open Access This article is licensed under a Creative Commons Attribution 4.0 International License, which permits use, sharing, adaptation, distribution and reproduction in any medium or format, as long as you give appropriate credit to the original author(s) and the source, provide a link to the Creative Commons license, and indicate if changes were made. The images or other third party material in this article are included in the article's Creative Commons license, unless indicated otherwise in a credit line to the material. If material is not included in the article's Creative Commons license and your intended use is not permitted by statutory regulation or exceeds the permitted use, you will need to obtain permission directly from the copyright holder. To view a copy of this license, visit http://creativecommons.org/licenses/by/4.0/.

(c) The Author(s) 2017

\footnotetext{
${ }^{1}$ Bigelow Laboratory for Ocean Sciences, 60 Bigelow Drive, East Boothbay, ME 04544, USA. ${ }^{2}$ Thermo Fisher Scientific Baltics, Graiciuno 8, LT-02241 Vilnius, Lithuania. ${ }^{3}$ Department of Marine Biology, Texas A\&M University at Galveston, Galveston, Texas 77553, USA. Correspondence and requests for materials should be addressed to R.S. (email: rstepanauskas@bigelow.org)
} 